\title{
Lembrando os 20 anos da Revista
}

\author{
Recalling the 20 years of our journal
}

\author{
Edgar Chagas Diefenthaeler, Gisele Gus Manfro
}

Neste ano da comemoração dos 30 anos da Revista de Psiquiatria do Rio Grande do Sul, fomos convidados a escrever sobre nossas contribuições para a trajetória da Revista, que, quando assumimos como editores, acabava de completar seus 20 anos. Nestes últimos 10 anos, a Revista em muito se consolidou e encontra-se em um nível compatível com o progresso da psiquiatria como especialidade médica, acompanhada da evolução científica do nosso meio durante esse mesmo período. Porém, há 10 anos, estávamos iniciando um longo e contínuo processo e lembramo-nos do convite feito pela Dra. Neusa Lucion para assumirmos esse cargo que, pela primeira vez, seria exercido por dois colegas. Pensamos que o trabalho seria interessante e que poderíamos contribuir, cada um de nós, com nossas características pessoais e marcos teóricos, para reformular e modernizar a Revista. Contamos com a ajuda do Dr. Calich, o editor que nos antecedeu e que aportou informações relevantes para a nossa arrancada. Posteriormente, constituímos o Conselho Editorial, que trabalhou de forma intensa e agradável. É trazida à lembrança a satisfação de, juntamente com esse eficiente Conselho e o auxílio da secretária Sandra Schmaedecke, ter sido um profícuo trabalho. Durante os anos de 2000 e 2001, concluímos o longo processo de inclusão da nossa Revista na PsychoINFO, a maior e mais abrangente base de dados sobre referências bibliográficas na área da psicologia, após criteriosa análise pelos revisores da American Psychological Association, que atestou a qualidade internacional da nossa Revista.

Com nove fascículos editados nos 2 anos de nossa gestão, retomamos a periodicidade e a atualidade das publicações, que asseguram a indexação internacional, que abriu caminho para inclusões em outras bases de dados. Para tal, avaliamos 63 artigos de diversas áreas de interesse: psiquiatria clínica e biológica, psicoterapias, psicanálise, psiquiatria da infância e adolescência, patologias ligadas à família, álcool e drogas. Divulgamos apresentações das principais atividades desenvolvidas pela Associação de Psiquiatria do Rio Grande do Sul, como o XIV Ciclo de Avanços e a V Jornada Gaúcha. Contamos com todo o apoio da diretoria, em especial da Dra. Neusa Lucion, que disponibilizou os recursos necessários para as edições. Matérias relativas à Revista tiveram destaque em seis números do Jornal da nossa Associação durante esse período.

Valiosas colaborações auxiliaram a colocar nossa Revista em destaque, como a participação de colegas da Associação de Psiquiatria do Rio Grande do Sul, das demais federadas de nosso estado e do país, assim como da Associação Psicanalítica Argentina e do Instituto Psicossomático de Buenos Aires, além de outros. Como nos mantivemos fiéis aos seus idiomas de origem, a Revista contou com artigos escritos em inglês e espanhol.

Com a publicação do volume 23 da Revista de Psiquiatria do Rio Grande do Sul, concluímos nosso trabalho. Tivemos o cuidado de publicar temas que abrangessem as diferentes áreas de estudo de nossos leitores, com ênfase em artigos originais ou de atualização e revisão que fossem de interesse para nosso público. Além disso, o Conselho Editorial teve sempre uma atitude receptiva com os colaboradores, exercendo uma função didática para com aqueles colegas que estavam se iniciando na árdua e prazerosa tarefa de escrever e publicar um artigo científico. Dessa forma, pensamos ter dado nossa contribuição ao vasto conhecimento científico de nosso meio, enriquecendo nosso trabalho diário, nossa convivência e nossa integração, segundo o que sempre se propôs a Associação de Psiquiatria do Rio Grande do Sul. 